\title{
Podmiotowość prawnomiędzynarodowa korporacji międzynarodowych wyzwaniem dla systemu ochrony inwestycji zagranicznych
}

\section{Wprowadzenie}

Zagadnienie podmiotowości prawnomiędzynarodowej korporacji międzynarodowych daje ciekawy ogląd problemów i wyzwań, jakie pojawiają się we współczesnym prawie międzynarodowym. W piśmiennictwie euroatlantyckiej doktryny prawa międzynarodowego problematyka jest obecna od lat sześćdziesiątych ubiegłego wieku (tj. od ponad pięćdziesięciu lat) i doczekała się już bardzo bogatej literatury ${ }^{1}$ (także

${ }^{1}$ P.T. Muchlinski, Multinational Entreprises \& the Law, Oxford 2007; P. Malanczuk, Multinational Enterprises and Treaty-Making - A Contribution to the Discussion on Non-State Actors and the "Subjects" of International Law, w: Multilateral Treaty-Making, seria Nijhoff Law Specials, 2000, s. 45-72; Foreign Investments in Developing Countries - Legal Personality of Multinationals in International Law, "Netherlands Yearbook of International Law” 1983, vol. 14, s. 87-131; J.E. Alvarez, Are Corporations "Subjects” of International Law?, "Santa Clara Journal of International Law" 2011, no. 9, s. 1-35; J. Wouters, A.L. Chané, Multinational Corporations in International Law, Leuven 2013, s. 1-20; G.P. Calliess, J. Mertens, Transnational Corporations, Global Competition Policy, and the Shortcomings of Private International Law, "Indiana Journal of Global Legal Studies” 2011, vol. 18, iss. 2, s. 843-872; P. Dumberry, L'entreprise, sujet de Droit international? Retour sur la question à la lumière des développements récents du droit international des investissements, "Revue générale de droit international public" 2004, no. 1, s. 103-122; P. Dumberry, É. Labelle-Eastaugh, Non-state Actors in International Investment Law: The Legal Personality of Corporations and NGOs in the Context of Investor-state Arbitration, w: Participants in the International Legal System: Multiple Perspectives on Non-state Actors in International Law, ed. by J. D'Aspremont, Oxford 2011, s. 360-371. 
w Polsce ${ }^{2}$ ). Pomimo wnikliwych analiz licznych argumentów „za i przeciw" nie została jednoznacznie przesądzona kwestia posiadania przez korporacje ponadnarodowe podmiotowości prawnomiędzynarodowej.

Korporacje międzynarodowe ${ }^{3}$ są ważnymi i niekwestionowanymi aktorami stosunków międzynarodowych i gospodarki światowej. Faktyczne uczestnictwo w stosunkach międzynarodowych i w międzynarodowym obrocie prawnym nie jest wszakże jeszcze równoznaczne z możliwością podejmowania określonych działań mających doniosłość prawną i nie jest równoznaczne z przypisaniem im podmiotowości prawnomiędzynarodowej. Nie ma przesądzającego charakteru gotowość czy też zdolność do posiadania przymiotu podmiotowości prawnomiędzynarodowej przez same korporacje międzynarodowe, albowiem ta kwestia wymaga jeszcze uznania ze strony całej społeczności międzynarodowej, a w szczególności jej głównych aktorów, czyli państw.

Nawet najbardziej entuzjastycznie podchodzący do tematu eksperci prawa międzynarodowego postulujący uznanie podmiotowości prawnomiędzynarodowej korporacji międzynarodowych ostrożnie wyznaczają granice i cele takich rozważań. Dość wspomnieć w tym miejscu zwolennika uznania podmiotowości prawnomiędzynarodowej korporacji międzynarodowych K. Karskiego, który zastrzega z góry, że problematyka ma swój określony „zakres” (zakres podmiotowy $)^{4}$.

W niniejszym artykule przeprowadzono analizę dwóch zagadnień: czy na obecnym etapie rozwoju międzynarodowego prawa inwestycyjnego została przesądzona podmiotowość korporacji międzynarodowych oraz czy kwestia podmiotowości prawnomiędzynarodowej korporacji międzynarodowych przyczyni się do zmian w systemie ochrony inwestycji zagranicznych.

${ }^{2}$ Zob. K. Karski, Osoba prawna prawa wewnętrznego jako podmiot prawa międzynarodowego, Warszawa 2009; Korporacje transnarodowe. Jeden temat, różne spojrzenia, pod red. J. Menkesa, T. Gardockiej, Warszawa 2010; K. Oleszczuk, Odpowiedzialność korporacji transnarodowych za naruszenia praw człowieka w świetle prawa międzynarodowego, w: Wybrane problemy wspótczesnego prawa międzynarodowego (publikacja pokonferencyjna), pod red. K. Lankosza, G. Sobola, Kraków 2013, s. 22-37; I. Wrońska, Korporacje transnarodowe a ochrona praw człowieka, "Zarządzanie i Finanse" 2013, nr 11, s. 469-492.

${ }^{3}$ Termin ten po raz pierwszy został zastosowany przez Davida Lilienthala w $1960 \mathrm{r}$. podczas konferencji w Carnegie Mellon University.

${ }^{4} \mathrm{~K}$. Karski, Zakres podmiotowości korporacji transnarodowej w prawie międzynarodowym, w: Korporacje transnarodowe..., s. 338. 


\section{Zdolność korporacji międzynarodowych do bycia podmiotem prawa międzynarodowego}

Od czasu wydania przez Międzynarodowy Trybunał Sprawiedliwości (MTS) opinii doradczej z 1949 r. w sprawie odszkodowań za szkody poniesione w służbie Narodów Zjednoczonych ${ }^{5}$, jak się wydaje, pozostało bardzo niewiele argumentów przemawiających za tym, by osoby prawne działające $\mathrm{w}$ ramach struktur organizacyjnych określanych mianem "korporacji międzynarodowych"6 nie mogły posiadać zdolności do bycia podmiotem prawa międzynarodowego, przynajmniej w takim zakresie, w jakim przymiotem tym mogą cieszyć się osoby fizyczne czy też organizacje międzynarodowe.

Ani powyżej przytoczone orzeczenie, ani też doktryna nie próbują sugerować, że korporacje międzynarodowe mogłyby mieć podmiotowość prawnomiędzynarodową równorzędną państwom. Z drugiej strony nie należy lekceważyć potęgi czy nawet funkcji sugestywnej definicji prawnych, które powodują, że eksperci określonych dyscyplin prawnych starają się czy też dążą do jednolitego traktowania podmiotów należących do tej samej kategorii lub ich zrównywania.

W tym miejscu przypomnieć należy pojemnie brzmiącą formułę definicji zaproponowaną przez L. Ehrlicha, zgodnie z którą do kategorii podmiotów prawa międzynarodowego zalicza się „uczestników stosunków międzynarodowych, posiadających prawa i obowiązki wynikające bezpośrednio z prawa międzynarodowego"7. Zdumiewające jest jednak to, że to podstawowe dla prawa międzynarodowego pojęcie nie doczekało się w doktrynie polskiej, poza monografią L. Ehrlicha z 1949 r., szerszych rozważań. Przyjęło się przedstawiać zagadnienie w dość praktycznym ujęciu. A. Wyrozumska i W. Czapliński proponują taki oto opis instytucji podmiotowości prawnomiędzynarodowej:

\footnotetext{
${ }^{5}$ I.C.J. Reports 1949 , s. 181-182.

${ }^{6}$ Wytyczne OECD dla korporacji międzynarodowych (ang. OECD Guidelines for Multinational Enterprises) charakteryzują w następujący sposób "korporacje międzynarodowe": „Te przedsiębiorstwa działają we wszystkich sektorach gospodarki. Zalicza się do nich spółki i inne podmioty założone w więcej niż jednym państwie i tak ze sobą powiązane, że mogą koordynować swoje działania w różny sposób. Zwykle jeden lub kilka podmiotów wywiera decydujący wpływ na działalność innych, zaś stopień autonomii w ramach całości korporacji międzynarodowej jest zróżnicowany. Struktura właścicielska może być prywatna, państwowa lub mieszana" [tłum. własne - E.K.].

${ }^{7}$ L. Ehrlich, Zagadnienie podmiotowości prawa narodów, Warszawa 1949, za: Wielka encyklopedia prawa, Białystok-Warszawa 2000, s. 656
} 
„Tradycyjnie najważniejszymi podmiotami prawa międzynarodowego są państwa i dlatego im poświęcimy najwięcej miejsca", a w dalszej części przedstawiają przykłady podmiotów o ograniczonej podmiotowości prawnomiędzynarodowej, w tym wskazując na osoby prawne ${ }^{8}$.

Wszelkie próby opisu pojęcia i umieszczania w jego zakresie tak wielu podmiotów skutkują tym, że samo określenie „podmiot prawa międzynarodowego" bardzo niewiele wyjaśnia, a jeśli prowadzi do daremnych porównań (np. z państwami), to być może samo w sobie jest mylące lub zbędne. Nieoczywistość funkcji i celu posługiwania się tym pojemnym pojęciem powoduje, że doktryna coraz częściej korzysta z nienormatywnego pojęcia "uczestników" czy też "aktorów" prawa międzynarodowego. W doktrynie polskiej do tych pojęć odwoływał się M. Perkowski ${ }^{9}$.

Brak jednoznacznej definicji „podmiotowości” („podmiotów”) czy częstokroć zamienne stosowanie pokrewnych terminów jest także symptomem niepewności co do konsekwencji posługiwania się terminem bazowym. Niewykluczone, że zagadnienie jest zbytnio "mitologizowane", albowiem proces włączania do grona "podmiotów prawa międzynarodowego" podmiotów innych niż państwa jest raczej naturalny (spontaniczny i „nieodgórny”) i nie dotyczy jedynie tak kontrowersyjnej problematyki jak rosnąca w siłę faktyczna i prawna pozycja korporacji międzynarodowych, lecz w równym stopniu obejmuje osoby fizyczne, organizacje pozarządowe (NGO-sy) czy związki wyznaniowe.

\section{Charakter podmiotowości prawnomiędzynarodowej korporacji międzynarodowej}

Jeśli przyjąć, że kategoria "podmiotów prawa międzynarodowego" jest pojemna, złożona i zróżnicowana, to należałoby się zastanowić, jaki charakter, czy też jakie kwantyfikatory są właściwe dla opisu podmiotowości prawnomiędzynarodowej korporacji międzynarodowych. Z całą pewnością, co już na wstępie zostało zasygnalizowane, nie zakłada się „pełnej” podmiotowości międzynarodowej w przypadku korporacji międzynarodowych. Ostrożna ocena poparta poniżej przedstawionymi

\footnotetext{
${ }^{8}$ W. Czapliński, A. Wyrozumska, Prawo międzynarodowe publiczne. Zagadnienia systemowe, Warszawa 1999, s. 110-111.

${ }^{9}$ M. Perkowski, Koncepcja "non-state actors" a umiędzynarodowienie regionów, "Białostockie Studia Prawnicze" 2012, nr 2, s. 95-103.
} 
argumentami nakazuje wobec tego opisać tę podmiotowość jako, w najlepszym razie, ograniczoną („niepełną"), pochodną i niesamodzielną, względną i funkcyjną. L. Ehrlich wskazywał na niesuwerenny, "nietradycyjny" (tylko państwom przypisywał podmiotowość o tradycyjnym charakterze), niepełny i pochodny charakter podmiotowości prawnomiędzynarodowej osób prawnych ${ }^{10}$.

Po pierwsze, gdy przedstawia się argumenty za uznaniem podmiotowości prawnomiędzynarodowej, to oczywistym punktem odniesienia będą państwa, które zasadniczo mogą cieszyć się w pełni podmiotowością prawnomiędzynarodową. Właściwymi kategoriami opisującymi podmiotowość prawnomiędzynarodową państw jest m.in.: suwerenność, terytorium, zdolność do bycia podmiotem praw i obowiązków, zdolność do zawierania umów międzynarodowych, odpowiedzialność międzynarodowa, stanowienie o wojnie i pokoju, jurysdykcja, polityka zagraniczna, zdolność do utrzymywania stosunków dyplomatycznych itd. Za trzy podstawowe kryteria świadczące o podmiotowości prawnomiędzynarodowej tradycyjnie uznaje się: prawo do zawierania umów międzynarodowych, czynne i bierne prawo legacji (uprawnienie podmiotu prawa międzynarodowego do wysyłania swoich i przyjmowania cudzych przedstawicieli dyplomatycznych) oraz zdolność procesowa (łac. locus standi) do dochodzenia roszczeń i ponoszenia odpowiedzialności międzynarodowej.

Korporacja międzynarodowa bardzo wielu powyższych przymiotów nie posiada (np. terytorium, jurysdykcji, polityki zagranicznej, zdolności do utrzymywania stosunków dyplomatycznych) i co do zasady nie uczestniczy w pełni w kształtowaniu wielu aspektów prawa międzynarodowego (np. zasadniczo nie uczestniczy w stanowieniu norm prawa międzynarodowego czy też nie posiada locus standi, czyli zdolności do wnoszenia skarg przed najważniejszy organ sprawiedliwości międzynarodowej, tj. Międzynarodowy Trybunał Sprawiedliwości). K. Karski wskazuje, że korporacje międzynarodowe nie mają przede wszystkim atrybutu suwerenności $\mathrm{w}$ rozumieniu prawa międzynarodowego ${ }^{11}$. Natomiast okoliczność posiadania niektórych z wyżej wymienionych atrybutów może być przejawem podmiotowości międzynarodowej korporacji międzynarodowej. Korporacja międzynarodowa może być bowiem stroną umowy międzynarodowej, może pozwać państwo przed

\footnotetext{
${ }^{10}$ L. Ehrlich, op. cit.

${ }^{11}$ K. Karski, Zakres podmiotowości..., op. cit., s. 178-179.
} 
trybunał arbitrażowy na podstawie niektórych typów umów międzynarodowych (np. umów bilateralnych o ochronie i popieraniu inwestycji, ang. Bilateral Investment Treaty - BIT) lub też można jej przypisać odpowiedzialność wynikającą z norm prawa międzynarodowego. Pogląd A. Wyrozumskiej i W. Czaplińskiego, że „[...] fakt zawierania przez nie umów z państwami lub organizacjami międzynarodowymi nie kreuje ich podmiotowości międzynarodowej, ponieważ umowy te nie podlegają prawu międzynarodowemu, lecz prawu kontraktu (niekiedy jednak kontrakt przewiduje ogólne zasady prawa międzynarodowego jako prawo właściwe dla umowy)"12, po wnikliwym wczytaniu się w jego treść, nie wydaje się $\mathrm{w}$ istocie argumentem przeciw uznaniu omawianej okoliczności za przejaw podmiotowości prawnomiędzynarodowej.

Po drugie, korporacje międzynarodowe zyskują atrybuty podmiotowości prawnomiędzynarodowej nie samodzielnie, ale jedynie z woli państw. Kontrakt z korporacją międzynarodową staje się umową międzynarodowa, gdy spełnione są dwa warunki: stroną kontraktu jest państwo i państwo to wyraża zgodę na poddanie postanowień kontraktu ocenie prawa międzynarodowego. Takie stanowisko przyjęto w sentencji orzeczenia arbitrażowego z 1977 r. w sprawie Texaco-Calasiatic (sprawa dotyczyła wydania przez Libię dekretu nacjonalizującego firmę Texaco, którą z rządem libijskim łączyła wcześniej zawarta umowa koncesyjna, odwołująca się w wielu miejscach do zasad prawa międzynarodowego ${ }^{13}$, które to stanowisko przełamało wcześniejszą linię orzeczniczą ustanowioną w sprawach pożyczek serbskich $i$ brazylijskich z 1929 r. ${ }^{14}$ oraz w sprawie Anglo-Iranian Oil Company ${ }^{15}$ (wcześniejsza linia orzecznicza stanowiła, że $z$ faktu zawarcia umowy przez państwo ze spółka, tj. podmiotem prawa wewnętrznego, nie sposób wyciągnąć wniosku, iż umowa podlega prawu międzynarodowemu, a w konsekwencji też, iż stanowi o uprawnieniach i obowiązkach prawnomiędzynarodowych, a tym samym kształtuje podmiotowość prawnomiędzynarodową dla stron tej umowy). Co istotne, w treści orzeczenia Texaco-Calasiatic opowiedziano się za możliwością wywiedzenia

\footnotetext{
${ }^{12}$ W. Czapliński, A. Wyrozumska, op. cit.

${ }^{13}$ Texaco Overseas Petroleum Co \& California Asiatic Oil CO. v. Libyan Arab Republic, orzeczenie arbitrażowe z 19 I 1977 r.

${ }^{14}$ Orzeczenia Stałego Trybunału Sprawiedliwości Międzynarodowej z 12 VII $1929 \mathrm{r}$. w sprawach: France v. Serbia, 1929 PCIJ 5, Series A, No. 21 and 22, oraz Brazil v. France, 1929, PCIJ Series A, No. 21.

${ }^{15}$ Wyrok MTS z 22 VII 1952 r. w sprawie Anglo-Iranian Oil Co. (United Kingdom v. Iran), ICJ Rep 93, ICGJ 188 (ICJ 1952).
} 
podmiotowości prawnomiędzynarodowej korporacji międzynarodowej $\mathrm{z}$ faktu zawarcia umowy poddanej prawu międzynarodowemu.

Wiele istotnych praw i obowiązków korporacji międzynarodowej wynika z norm prawa międzynarodowego traktatowego, na które wyraziły zgodę państwa (a to znaczy, że korporacje międzynarodowe nie mogą samodzielnie, bez woli państw, pretendować do takiego statusu). To właśnie na podstawie norm wynikających z traktatów dwustronnych (np. BIT-ów) lub umów wielostronnych (np. Konwencji waszyngtońskiej z dnia 18 marca 1965 r. o rozstrzyganiu sporów inwestycyjnych między państwami a obywatelami innych państw - ICSID ${ }^{16}$ ) korporacje mogą pozywać państwa przed trybunały arbitrażowe za naruszenie norm prawa międzynarodowego. Zwrócić uwagę należy również na zawarte $\mathrm{w}$ postanowieniach umów BIT tzw. klauzule ramowe (ang. umbrella clause) czy też odwołanie się w ramach umowy BIT do zasady dotrzymywania zobowiązań (łac. pacta sunt servanda), które to klauzule stanowią o rozciągnięciu prawnomiędzynarodowej ochrony przewidzianej postanowieniami danego BIT na wszelkie zobowiązania zaciągnięte przez państwo wobec inwestora (w tym o charakterze wyłącznie cywilnoprawnym) i tym samym „wyniesienie" ochrony prawnej dla konkretnego zobowiązania z poziomu porządku wewnętrznego na poziom prawnomiędzynarodowy. Uprawnienia korporacji międzynarodowej trwają tak długo, jak długo pozostaje w mocy dany akt prawa międzynarodowego, którym zechciało związać się dane państwo, czy też tak długo, jak dane państwo zechciało się związać danym aktem prawnym.

Korporacje mogą być (jeśli tylko moga, a tego zagadnienia w tym miejscu artykuł nie przesądza) jedynie niesamodzielnymi podmiotami prawa międzynarodowego także z tego powodu, że ich istnienie uzależnione jest i oceniane na podstawie prawa wewnętrznego danego państwa. Korporacje międzynarodowe są przede wszystkim złożone z osób prawnych założonych na podstawie prawa wewnętrznego, mających swoje miejsce rejestracji (inkorporacji), siedzibę statutowych organów w określonym państwie, a ich władztwo korporacyjne w ramach korporacji międzynarodowej podlega przepisom jednego lub kilku statutów prawa właściwego (tzw. lex societatis). Byt korporacji międzynarodowej tak długo istnieje, jak długo na podstawie prawa wewnętrznego funkcjonują podmioty prawa wewnętrznego. Korporacje międzynarodowe, co jest już absolutnym truizmem, ani nie ustanawiają

${ }^{16}$ Polska jako jedyne z państw członkowskich Unii Europejskiej nie jest stroną tej konwencji. 
norm prawa wewnętrznego, którym muszą się podporządkować, ani nie uczestniczą (na szczeblu decyzyjnym, przy czym istnieją wyjątki ${ }^{17}$ ) $\mathrm{w}$ procesach tworzenia norm prawa traktatowego, przyjmując $\mathrm{w}$ takich sytuacjach pozycję pasywna, tj. podmiotów, które stosują normy prawa międzynarodowego.

Po czwarte, podmiotowość korporacji międzynarodowych jest względna i funkcyjna. Względność tego przymiotu wynika z charakteru norm traktatowych, z których wyczytuje się przejawy podmiotowości prawnomiędzynarodowej korporacji międzynarodowych. Normy traktatowe obowiązują strony umów międzynarodowych i nie mają charakteru erga omnes. W konsekwencji podmiotowość prawnomiędzynarodowa może być skuteczna tylko wobec stron umowy międzynarodowej. Pewnym wyjątkiem są sytuacje, gdy podmiotowość prawnomiędzynarodowa jest związana z okolicznością odpowiedzialności międzynarodowej za naruszenie norm ius cogens. Normy prawa międzynarodowego ius cogens stosuje się bezpośrednio do podmiotów innych niż państwa, a obejmują one takie zagadnienia jak zbrodnie wojenne, zbrodnie przeciwko ludzkości czy praca niewolnicza. W przypadku takich norm cała społeczność międzynarodowa ma interes w ochronie tych norm i dochodzeniu odpowiedzialności korporacji międzynarodowej.

Podmiotowość międzynarodowa jest funkcyjna $\mathrm{z}$ tego względu, że ograniczona jest do określonej dziedziny prawa międzynarodowego i specyficznego celu, jakiego osiągnięcie się zakłada. Może wobec tego okazać się, iż w pewnych obszarach korporacje międzynarodowe będą cieszyć się podmiotowością prawnomiędzynarodową w zbliżonym do państw zakresie, a w innych dziedzinach prawa międzynarodowego, w dużej mierze wobec milczenia prawa międzynarodowego, takiej podmiotowości nie sposób będzie domniemywać. Przesądzenia podmiotowości korporacji międzynarodowych, przykładowo, w obszarze odpowiedzialności międzynarodowej za naruszenie norm ius cogens nie sposób automatycznie rozciągnąć na obszar międzynarodowego prawa inwestycyjnego.

${ }^{17}$ Korporacje międzynarodowe uczestniczą aktywnie w wypracowywaniu międzynarodowych standardów prawa pracy w ramach Międzynarodowej Organizacji Pracy (ILO), na podstawie niewiążącego instrumentu wypracowanego w 1977 r. (i zmienianego w 2000 i 2006 r.) - ILO Tripartite Declaration of Principles Concerning Multinational Entreprises and Social Policy; zob. także: J.L Cernic, Corporate Responsibility for Human Rights: Analyzing the ILO Tripartite Declaration of Principles Concerning Multinational Enterprises and Social Policy, "Miskolc Journal of International Law” 2009, vol. 6, no. 1, s. 24-34. 


\section{Korporacje międzynarodowe jako beneficjenci norm prawa międzynarodowego dotyczącego ochrony inwestycji}

Ze względu na to, że to korporacje międzynarodowe są głównymi uczestnikami międzynarodowego obrotu gospodarczego, to i system ochrony inwestycji zagranicznych, który formułował się przez ostatnie stulecie, ewoluował w kierunku uwzględnienia specyfiki funkcjonowania także (a może przede wszystkim) tych podmiotów.

Dochodzenie roszczeń $w$ tradycyjnym podejściu prawa międzynarodowego realizowane było w ramach ochrony dyplomatycznej. Ochrona dyplomatyczna sprawowana przez państwa jedynie wobec własnych obywateli (osób fizycznych i prawnych) sięgała jeszcze czasów średniowiecza, zaś jako płaszczyzna sporów angażujących państwa chroniące interesy swoich obywateli została szerzej rozpowszechniona w stosunkach międzynarodowych w II połowie XIX w. Wówczas to państwa $\mathrm{w}$ imię interesów poszkodowanych obywateli prowadziły spory bądź przed obliczem innego suwerena jako arbitra (w ramach dobrych usług), bądź też przed powoływanymi komisjami mieszanymi (tzw. trybunałami ad hoc). W I połowie XX w., wraz z rozwojem stałego sądownictwa międzynarodowego, zaczęła się kształtować instytucja ochrony dyplomatycznej realizowana $\mathrm{w}$ drodze procesu międzynarodowego. Spór brytyjsko-grecki w sprawie Mavrommatis z $1924 \mathrm{r} .{ }^{18}$ uznaje się za precedensowy i kształtujący w tradycji prawa międzynarodowego mechanizm ochrony dyplomatycznej.

Ochrona dyplomatyczna osób prawnych była niemal od początku dość złożonym zagadnieniem, ale pełne spektrum trudności unaoczniły dopiero sprawy związane $\mathrm{z}$ ochroną interesów korporacji międzynarodowych. Warunkiem objęcia ochroną dyplomatyczną i wniesienia skargi do sądu międzynarodowego (tzw. locus standi) było m.in. posiadanie przez osoby prawne "obywatelstwa" państwa wnoszącego skargę $^{19}$. O ile powyższy warunek mógł sprawdzać się w warunkach rozwijającego się w I połowie XX w. obrotu gospodarczego, jasnych

${ }^{18}$ Sprawa Concessions Mavrommatis en Palestine, Grecja p. Wielkiej Brytanii, orzeczenie z 30 VIII 1924 r., PCIJ, 1924, Rec. Série A, no. 2.

${ }^{19} \mathrm{Na}$ kontrowersje i niezręczności związane z użyciem terminu "obywatelstwo" w odniesieniu do osób prawnych wskazywał J. Sandorski, przyjmujący to sformułowanie. Termin "obywatelstwo osób prawnych" bywa również zastępowane terminem "przynależność państwowa", zob. J. Sandorski, Opieka dyplomatyczna a międzynarodowa ochrona praw człowieka, Poznań 2006, s. 158 i n. 
i oczywistych powiązań osób prawnych z danym państwem, to w miarę upływu lat i powstawania grup kapitałowych o zasięgu obejmującym kilka państw i angażujących inwestorów z różnych państw, sprawy zaczęły się komplikować. Instytucja ochrony dyplomatycznej w tradycyjnym kształcie nie podążała za tymi zmianami. Spółka, która poniosła szkodę, musiała co do zasady posiadać obywatelstwo państwa wnoszącego skargę (a poszkodowanymi były najczęściej spółki lokalne, założone przez zagranicznych inwestorów w państwie, od którego dochodzono szkody). Uprawnienia takiego zasadniczo pozbawione było państwo ojczyste akcjonariusza (czyli państwo ojczyste spółki matki czy też spółki powiązanej). Spółki również w wyniku przejęć narażone były na utratę dotychczasowego obywatelstwa na rzecz obywatelstwa państwa trzeciego lub pozwanego (taki przypadek miał miejsce w wyniku nacjonalizacji w 1956 r. przez Egipt spółek angielskich eksploatujących kanał Suezu ${ }^{20}$ ) i w takiej sytuacji państwo pierwotnego pochodzenia spółki mogłoby utracić uprawnienie do dochodzenia szkody w ramach ochrony dyplomatycznej.

Sztandarowa sprawa Barcelona Traction zakończona przed MTS wyrokiem w $1970 \mathrm{r}^{21}$ ukazuje te problemy. Barcelona Traction w okresie toczącego się od końca lat pięćdziesiątych XX w. sporu była prężną korporacją międzynarodowa, założoną w 1911 r. przez Amerykanina Freda Starka Pearsona, który biorąc pod uwagę korzyści podatkowe, zarejestrował ją nie w Stanach Zjednoczonych, lecz w Toronto (Kanada). Spółka prowadziła działalność w państwach Zachodniej Półkuli, a z czasem rozszerzyła działalność na obszar Europy, była m.in. notowana na giełdzie w Londynie, inwestowała w kilku państwach w spółki lokalne (głównie z branży energetycznej), a w samej Hiszpanii posiadała dwanaście spółek zależnych. W latach dwudziestych akcjonariat przeszedł w ręce belgijskie, przy czym na okres II wojny światowej z ostrożności akcjonariuszem został fundusz amerykański, zaś po zakończeniu działań wojennych akcje spółki Barcelona Traction powróciły do akcjonariuszy belgijskich, którzy w latach pięćdziesiątych posiadali ok. 88\% udziału w kapitale zakładowym. Spór przed MTS zaangażował Belgię i Hiszpanię (Hiszpania oskarżana była o niezgodne z prawem międzynarodowym wywłaszczenie korporacji Barcelona Traction z czterech

${ }^{20}$ Zob. R. Delson, Nationalization of the Suez Canal Company: Issues of Public and Private International Law, „Columbia Law Review” 1957, vol. 57, no. 6, s. 755-786.

${ }^{21}$ Wyrok MTS z 5 II 1970 r. w sprawie Barcelona Traction (Belgium v. Spain), I.C.J., Recueil 1970, s. 1. 
spółek funkcjonujących na rynku hiszpańskim). W 1970 r. MTS wydał orzeczenie odrzucające skargę Belgii ze względu na brak locus standi do wniesienia skargi przed MTS. Spółka Barcelon Traction, jako podmiot zarejestrowany w Toronto, była w ocenie MTS spółką kanadyjską i tylko Kanada była uprawniona do dochodzenia roszczeń na rzecz Barcelona Traction.

Sprawa Barcelona Traction była przyczynkiem do ożywionej dyskusji na temat przesłanek i efektywności instytucji ochrony dyplomatycznej także z tego istotnego powodu, że skarga byłaby dopuszczalna, gdyby wniosła ją Kanada. Co ciekawe, Kanada początkowo rozważała taką ewentualność, jednakże nie dostrzegając istotnego faktycznego interesu w popieraniu skargi (także wobec zabiegów dyplomacji hiszpańskiej), z tego zamiaru wycofała się. Ochrona dyplomatyczna jest bowiem instrumentem nieobligatoryjnym dla państw wyłącznie uprawnionych do jej uruchomienia (ani spółka, ani akcjonariusze spółki nie mają prawnych możliwości wyegzekwowania od uprawnionego państwa ojczystego podjęcia działań prawnych na rzecz poszkodowanych podmiotów), a przy tym wykorzystywanym koniunkturalnie i politycznie. Mechanizm uruchomienia ochrony dyplomatycznej został jednocześnie obudowany rygorystycznymi przesłankami warunkującymi dopuszczalność samego wniesienia skargi (oprócz obywatelstwa państwa obejmującego ochroną dyplomatyczną w momencie wystąpienia szkody i wniesienia skargi konieczne jest także wyczerpanie środków odwoławczych przewidzianych prawem krajowym i zgodnie z prawem zachowanie podmiotu poszkodowanego, tj. przy zachowaniu tzw. "czystych rąk $^{\prime \prime 2}$ ), wobec czego z punktu widzenia poszkodowanych podmiotów gospodarczych dostępność i skuteczność tego nadal obowiązującego w prawie międzynarodowym mechanizmu wydaje się iluzoryczna.

Rygoryzm i konceptualizm prawniczy tradycyjnej ochrony dyplomatycznej spowodował nacisk środowisk biznesowych na rządy państw rozwijających się, które od lat siedemdziesiątych rozpoczęły na masową skalę praktykę zawierania umów dwustronnych o wzajemnym popieraniu i ochronie inwestycji (ang. Bilateral Investment Treaty - BIT). Praktykę zawierania tego typu umów, których jest już ponad $3000 \mathrm{w}$ skali globalnej, rozpoczęły Stany Zjednoczone. BIT-y zawierają dwa podstawowe elementy: zobowiązanie państw do odpowiedniego traktowania

${ }^{22}$ Zob. J.C. Wittenberg, La recevabilité des réclamations devant les juridictions internationals, "Recueil des Cours de l'Académie de Droit international de la Haye” 1932, vol. 41, s. 1-136. 
inwestorów z danego państwa oraz stanowią o zgodzie państw na poddanie się mechanizmowi dochodzenia tych zobowiązań w drodze arbitrażu międzynarodowego ${ }^{23}$. Konstrukcyjnie postanowienia BIT są też tak sformułowane, że zazwyczaj zabraniają określonych działań wobec inwestorów. Najczęściej sformułowane zakazy, których adresatami są państwa-strony BIT, dotyczą: wywłaszczenia, ograniczenia w wymienialności walut czy wprowadzenia środków o charakterze dyskryminacyjnym.

Beneficjentami ochrony inwestycji w ramach umów o ochronie inwestycji stali się inwestorzy jedynie pochodzący z państw-stron tych umów, przy czym umowy te ustanawiają różne sposoby i kryteria ustalania pochodzenia podmiotów gospodarczych. Postanowienia w tym zakresie mają różną szczegółowość. Różnice wynikają z różnorodnych polityk traktatowych państw, wykładni umów, stanowisk państw-stron umów, praktyki stosowania umów oraz niejednokrotnie stanowiska organu (trybunału arbitrażowego) rozstrzygającego na podstawie postanowień danej umowy o ochronie inwestycji. Co ciekawe, trybunały arbitrażowe zastosowały w kilku sprawach dość rozszerzającą wykładnię, przyjmując do rozpatrzenia skargi wnoszone przez spółki powiązane kapitałowo z poszkodowaną spółką (tak było w sprawach: Amco przeciwko Indonezji z 1983 r. ${ }^{24}$, AMT przeciwko Zairowi z 1997 r. ${ }^{25}$, Alex Genin przeciwko Estonii z 2001 r. ${ }^{26}$ oraz CME przeciwko Czechom z 2001 r. ${ }^{27}$ ).

BIT-y są jednym $z$ typów traktatowego uregulowania ochrony inwestycji kapitałowych podmiotów gospodarczych. Ochronę inwestycji dokonywanych przez grupy kapitałowe (a więc inwestycje zakupu akcji) przewidują także postanowienia obowiązujące państwa będące członkami Światowej Organizacji Handlu (World Trade Organization - WTO) i Organizacji Współpracy Gospodarczej i Rozwoju (Organization for

${ }^{23}$ J.W. Salacuse, The Emerging Global Regime for Investment, "Harvard International Law Journal" 2010, vol. 51, no. 2, s. 427-473; idem, BIT by BIT: The Growth of Bilateral Investment Treaties and Their Impact on Foreign Investment in Developing Countries, "The International Lawyer" 1990, vol. 24, no. 3, s. 655-675; M. Hallward-Driemeier, Do Bilateral Investment Treaties Attract FDI? Only a Bit and They Could Bite, "World Bank, Policy Research Working Paper" 2003, no. 3, s. 1-36.

${ }^{24}$ Amco v. Indonesia, Decision on Jurisdiction, 25 IX 1983 r., 1 ICSID Reports 389.

${ }^{25}$ AMT v. Zaire, Award, 21 II 1997, p. 1531, 5 ICSID Reports 11.

${ }^{26}$ Alex Genin, Eastern Credit Limited, Inc. and A.S. Baltoil v. The Republic of Estonia, Award, 25 VI 2001, 6 ICSID 241.

${ }^{27}$ CME Czech Republic B.V. (The Netherlands) v. The Czech Republic, Partial Award, 13 IX 2001. 
Economic Co-operation and Development - OECD), postanowienia umów o wolnym handlu (Free Trade Agreements - FTA) oraz postanowienia umów wielostronnych (np. art. 1 ust. 6 lit. b Traktatu Karty Energetycznej czy art. 1139 Północnoamerykańskiego Układu o Wolnym Handlu - NAFTA).

Reasumując, w ostatnich pięćdziesięciu latach system ochrony inwestycji dokonywanych także przez (i w ramach) korporacji międzynarodowych ewoluował od instytucji ochrony dyplomatycznej (instytucji stanowiącej o wyłącznym uprawnieniu państw do dochodzenia roszczeń w imieniu swoich obywateli) w kierunku mechanizmów umożliwiających podmiotom gospodarczym samodzielne dochodzenie od państw roszczeń związanych z dokonywanymi inwestycjami zagranicznymi. Powstał system, który według jednych jest przejawem kształtującego zwyczaju, według innych jest systemem zagregowanych norm, które są źródłem względnej podmiotowości prawnomiędzynarodowej inwestorów wobec państw-stron danego instrumentu prawa inwestycyjnego. System ten jednak nie oderwał się od kryterium „pochodzenia” (obywatelstwa) inwestora (inwestującej spółki), które należy wykazać w celu powołania się na uprawnienia wynikające $z$ konkretnego instrumentu prawa inwestycyjnego. Biorąc to pod uwagę, M. Jeżewski w 2011 r. podkreślał, że koncentrowanie się nawet na definicji "korporacji międzynarodowej" nie ma praktycznego znaczenia, skoro nadal istotą uruchomienia norm międzynarodowego prawa inwestycyjnego jest wykazanie "pochodzenia" (obywatelstwa) inwestora (choć jednocześnie wskazywał, że zauważalne są już pojawiające się tendencje do rozszerzania podmiotowości prawnomiędzynarodowej korporacji międzynarodowych $)^{28}$.

\section{Punkt wyjścia dla rozważań o podmiotowości korporacji międzynarodowych we współczesnym prawie międzynarodowym}

Punktem wyjścia dla wskazania argumentów przeciw podmiotowości prawnomiędzynarodowej korporacji międzynarodowych w międzynarodowym prawie inwestycyjnym jest zachowawcze stanowisko tradycyjnego nurtu prawa międzynarodowego w szerokim ujęciu. Podmiotom innym niż państwa zasadniczo odmawia się podmiotowości

${ }^{28}$ Zob. M. Jeżewski, Międzynarodowe prawo inwestycyjne, Warszawa 2011, s. 94. 
prawnomiędzynarodowej. Wstrzemięźliwe stanowisko doktryny dotyczy sytuacji, w których dla podmiotów prawa wewnętrznego wynikałyby przede wszystkim niezależne od woli państw i bezpośrednio stosowane prawa i obowiązki w obrocie międzynarodowym.

Ze zwyczajowego prawa międzynarodowego nie sposób również wywnioskować stanowiska wyjściowego. Brak powszechnie obowiązującej ${ }^{29}$ normatywnej definicji korporacji międzynarodowej (a więc brak kryteriów, które pozwoliłyby precyzyjnie ustalić wszystkich adresatów norm prawa międzynarodowego), a tym samym brak możliwości odniesienia tego pojęcia do kategorii "podmiotów prawa międzynarodowego", w dużej mierze utrudniają analizę zagadnienia z punktu widzenia jego ewolucji w czasie oraz perspektyw na przyszłość. Ostrożne stanowisko w tym względzie każe zająć okoliczność braku manifestowanej woli państw do przyjęcia norm, których skutki dla prawa międzynarodowego bardzo trudno przewidzieć. Zagadnienie "podmiotowości korporacji międzynarodowych" jest przedmiotem bogatych rozważań doktrynalnych, za którymi, poza nielicznymi próbami kodyfikacji, nie podążają wiążące zmiany w sferze normatywnej. Nawet John Ruggie, powołany w 2005 r. na funkcję Specjalnego Sprawozdawcy Narodów Zjednoczonych ds. praw człowieka i korporacji międzynarodowych oraz innych podmiotów gospodarczych ${ }^{30}$, ustalił w przygotowywanym pod jego kierunkiem Raporcie końcowym z prac nad projektem Norm dotyczacych korporacji międzynarodowych, że "korporacje międzynarodowe przeszły na arenie międzynarodowej ogromną zmianę, ale nie jest ona tak daleko idąca, jak na to wskazuje doktryna i środowiska organizacji pozarządowych"31. Prace nad projektem "Norm” spotkały się również z dużym oporem i krytyką ze strony samych zainteresowanych,

${ }^{29}$ Wyjątek stanowi wcześniej przytaczana definicja opisowa OECD, zob. przypis 6.

${ }^{30}$ Ang. UN Secretary-General's Special Representative on the Issue of Human Rights and Transnational Corporations and Other Business Enterprises (SRSG).

${ }^{31}$ Raport Komisji Praw Człowieka z dnia 9 II 2007 r.: The Special Representative of the Secretary-General, Report of the Special Representative of the Secretary General on the Issue of Human Rights and Transnational Corporations and Other Business Enterprises, John Ruggie, Business and Human Rights: Mapping International Standards of Responsibility and Accountability for Corporate Acts, delivered to the Human Rights Council, U.N. Doc. A/HRC/4/35. Ustalenia profesora J. Ruggiego analizuje E. Duruigbo, Corporate Accountability and Liability for International Human Rights Abuses: Recent Changes and Recurring Changes, "Northwestern Journal of International Human Rights" 2008, vol. 6, iss. 2, s. 222-261, zwł. s. 223, oraz A. Wallis, Data Mining: Lessons from the Kimberley Process for the United Nation's Development of Human Rights Norms for Transnational Corporations, "Northwestern Journal of International Human Rights" 2005, vol. 4, iss. 2, s. 388-417. 
tj. korporacji międzynarodowych. Ostatecznie prac nad projektem nie kontynuowano.

Stanowisko wyjściowe, zasadniczo odmawiające podmiotowości prawnomiędzynarodowej podmiotom innym niż państwa, zaważyło na tym, że proces przypisywania podmiotowości korporacjom międzynarodowym następuje stopniowo. Doktryna prawa międzynarodowego, organizacje międzynarodowe (np. ONZ czy OECD) oraz NGO-sy konsekwentnie przekonują państwa do konieczności upodmiotowienia korporacji międzynarodowych w celu efektywnego zastosowania wobec tych podmiotów przede wszystkim przepisów karnych, fiskalnych, pracowniczych i ochrony środowiska. Co do zasady, osoby prawne, na równi z osobami fizycznymi, a także obok organizacji międzynarodowych i państw, odpowiadają za czyny niezgodne z normami peremptoryjnymi (ius cogens). Logiczna wydaje się konkluzja, wywiedziona także ze swoistego milczenia prawa międzynarodowego co do zakresu uprawnień poszczególnych aktorów stosunków międzynarodowych, że to, co jest zakazane osobom fizycznym, to również jest zakazane osobom prawnym takim jak korporacje międzynarodowe, niezależnie od tego, czy jedyną motywacją ich działań jest chęć zysku, a może nawet ze względu na tę okoliczność.

Wywodzenie logicznych konkluzji ze stanu obecnego prawa międzynarodowego jest jak najbardziej uprawnione, wydaje się jednak, że konieczne jest jeszcze osadzenie tych zasad w skutecznym mechanizmie ich egzekwowania. Społeczność międzynarodowa dostrzega $\mathrm{w}$ tym zakresie istotny interes faktyczny i prawny. W odpowiedzialności korporacji międzynarodowej dostrzec można przede wszystkim możliwość zwiększenia efektywności uzyskania zadośćuczynienia za wyrządzoną krzywdę. W wielu wypadkach dochodzenie odpowiedzialności na podstawie przepisów prawa wewnętrznego nie przynosi pożądanych skutków, przede wszystkim może nie prowadzić do przypisania odpowiedzialności w tak daleko idącym rozmiarze (finansowym i wizerunkowym), jak ma to miejsce w wypadku odpowiedzialności za czyn niezgodny z prawem międzynarodowym. Możliwość uzyskania zadośćuczynienia od podmiotu prawa wewnętrznego, co do zasady, ograniczona jest do wypłacalności (wartości likwidacyjnej) tego podmiotu. Możliwość dochodzenia odpowiedzialności cywilnej od podmiotów powiązanych (np. od akcjonariuszy) jest dość skomplikowanym zagadnieniem, wymuszającym uciekanie się do instytucji „podniesienia zasłony korporacyjnej”, występującej 
zresztą $w$ ograniczonym zakresie $w$ nielicznych porządkach prawnych na zasadzie wyjątku od zasady autonomii osobowości prawnej spółki w obrocie gospodarczym. Natomiast odpowiedzialność osób zarządzających osobami prawnymi może nie mieć istotnego wpływu na działalność samych korporacji międzynarodowych i skuteczność uzyskania zadośćuczynienia. Dymisja czy rezygnacja osób zarządzających ze sprawowanych funkcji najczęściej „kończy sprawę", ale tylko w sferze wizerunkowej.

Powyżej opisany proces zorientowany jest na cel przypisania korporacjom międzynarodowym odpowiedzialności prawnomiędzynarodowej, zaś podmiotowość korporacji międzynarodowych pozostaje w funkcji tego celu. Podmiotowość prawnomiędzynarodowa byłaby w tym wypadku źródłem praw, obowiązków i odpowiedzialności korporacji międzynarodowej. Czy analogicznie konstruktywne, pragmatyczne i silne aksjologicznie podstawy da się wywieść także dla określenia podmiotowości prawnomiędzynarodowej korporacji międzynarodowych w obszarze międzynarodowego prawa inwestycyjnego?

\section{Argumenty za podmiotowością prawnomiędzynarodową korporacji międzynarodowych w systemie prawa inwestycyjnego}

Korporacje międzynarodowe są bytami abstrakcyjnymi i nienaturalnymi, a jeszcze bardziej metaforycznie rzecz ujmując - organizmami zagregowanych i zorganizowanych w określonym celu (przede wszystkim gospodarczym) grup ludzi. Mają wewnętrzne regulacje, strategie (zorientowane za zewnątrz i do wewnątrz), swoje "polityki", symbole, swoich "przywódców” (menedżerów) oraz grupy interesów (akcjonariuszy, spółki powiązane, sieć partnerów gospodarczych oraz społeczność lokalną zainteresowaną obecnością podmiotu gospodarczego jako podatnika i pracodawcy). Jeśli tak spojrzeć na te podmioty, to w większym stopniu przypominają one państwa niż osoby fizyczne. Analogie takie, oczywiście, nie mogą prowadzić do wiążących wniosków natury prawnej (i nie przesądzają one o podmiotowości prawnomiędzynarodowej). Kluczem do przyznania korporacjom międzynarodowym podmiotowości międzynarodowej jest nade wszystko wola państw, nie zaś nawet najlepiej przedstawione argumenty prawne i faktyczne, oparte ma intelektualnych i erystycznych wywodach. 
Obecnie, przyjmując bardzo otwarte podejście, korporacje międzynarodowe mają ograniczoną funkcjonalnie podmiotowość prawnomiędzynarodowa, przypisaną im z woli niektórych państw prowadzących aktywną politykę w zakresie ochrony inwestycji i tylko w wypadku możliwości wykazania przynależności (obywatelstwa podmiotu) do określonego państwa-strony umowy o ochronie inwestycji. Podmiotowość prawnomiędzynarodowa na cele międzynarodowego prawa inwestycyjnego zasadniczo sprowadza się do możliwości dochodzenia przed trybunałami arbitrażowymi odszkodowania za arbitralne, dyskryminacyjne i niezgodne z prawem międzynarodowym traktowanie zagranicznych inwestorów.

Po pierwsze, na dłuższą metę nie sposób obronić rygoryzmu i formalizmu stojącego za odmową podmiotowości prawnomiędzynarodowej korporacji międzynarodowych na cele międzynarodowego prawa inwestycyjnego. Jeśli toruje sobie drogę koncepcja podmiotowości funkcjonalnej w sferze praw człowieka, a równolegle korporacje międzynarodowe związują się z państwami traktatami kwalifikowanymi jako umowy międzynarodowe, a przy tym mogą pozywać państwa przed trybunały arbitrażowe, opierając się na postanowieniach niemal trzech tysięcy umów typu BIT, to można powiedzieć, że dzisiejsze międzynarodowe prawo inwestycyjne jest dość blisko przyznania, iż korporacje międzynarodowe posiadają i a priori mogłyby posiadać podmiotowość prawnomiędzynarodową także $\mathrm{w}$ ramach międzynarodowego prawa inwestycyjnego. Nie istnieja, poza oczywiście politycznymi, takie argumenty, które sprzeciwiałyby się uwolnieniu koncepcji z jej historycznych i dogmatycznych ograniczeń ${ }^{32}$. Jeśli w prawie międzynarodowym pojawia się wyraźna i powszechna tendencja do zwiększonej ochrony inwestorów zagranicznych, która realizuje się wobec podmiotów pochodzących z państw prowadzących aktywną politykę traktatową skutkującą zawarciem umów typu BIT z jak największą liczbą państw, to stosując rozumowanie odwołujące się do zasady wolności i równości w handlu, nie sposób odmówić takiej ochrony innym podmiotom międzynarodowego obrotu gospodarczego, za którymi niekoniecznie "jakieś państwa stoją" (a korporacje międzynarodowe mogłyby być takimi podmiotami, którym coraz trudniej przypisać jednoznaczną przynależność do określonego państwa). Źródłem takiego uprawnienia mógłby być

${ }^{32}$ Taki postulat formułuje m.in. profesor R. Higgins, zob. R. Higgins, Problems and Process: International Law and How We Use It, Oxford 1994, s. 49. 
zwyczaj (istnieje taki pogląd, w świetle którego postanowienia BIT-ów, głównie ze względu na ich liczbę, rozprzestrzenienie oraz analogiczne postanowienia i zbliżone cele, są przejawem kształtujących się norm prawa zwyczajowego ${ }^{33}$ ) lub traktat o powszechnym zasięgu (prace koncepcyjne w gronie ekspertów prawa międzynarodowego od dawna toczą się w Komisji Prawa Międzynarodowego ONZ oraz w grupach roboczych OECD).

Po drugie, można wskazać też na liczne argumenty odwołujące się do faktycznych potrzeb i struktury międzynarodowego obrotu gospodarczego, przemawiające za koniecznością uregulowania działalności korporacji międzynarodowych w oparciu o normy prawa międzynarodowego. Niektóre obszary czy też aspekty funkcjonowania korporacji międzynarodowych z założenia wykraczają poza jeden porządek prawny. Dotyczy to np. prawa kartelowego, konkurencji, ochrony praw własności intelektualnej, prawa autorskiego, finansowego (przepływów finansowych) czy niektórych aspektów prawa podatkowego.

Dotychczas, po części instynktownie, po części na podstawie pewnych tradycji prawnych, zjawiska związane z funkcjonowaniem korporacji międzynarodowej, widzianej jako międzynarodowy holding czy też grupa spółek powiązanych ze sobą strukturami właścicielskimi, oceniano ostrożnie z perspektywy kilku dziedzin prawa: prawa międzynarodowego, porządków wewnętrznych, norm kolizyjnych i prawa porównawczego. Badania komparatystyczne szwajcarskiego profesora Pierre'a Lalive'a pozwalają na sformułowanie wniosku, że tradycyjne sposoby określania porządku prawnego właściwego dla statusu prawnego poszczególnych spółek wchodzących w skład korporacji międzynarodowej, głównie na podstawie norm prawa prywatnego międzynarodowego (norm kolizyjnych), mogą prowadzić do nieadekwatnych rezultatów i ocen działalności korporacji międzynarodowej jako całości ${ }^{34}$. Normy prawa prywatnego międzynarodowego (normy kolizyjne) są różne w poszczególnych państwach, a stosują je organy rozstrzygające poszczególne zagadnienia na potrzeby postępowań przed tymi organami, zatem te normy nie sposób stosować w sposób

${ }^{33}$ P. Dumberry, Are BITs Representing the ,New' Customary International Law in International Investment Law?, „Penn State International Law Review, 2010, vol. 28, no. 4, s. 675-701; S.M. Schwebel, The Influence of Bilateral Investment Treaties on Customary International Law, "American Society of International Law Proceedings" 2004, vol. 98, s. 27-30.

${ }^{34} \mathrm{P}$. Lalive, Le droit applicable aux entreprises multinationales, Rapports généraux au IXe Congrès international de Droit comparé, Téhéran 1974, Bruxelles 1975, s. 361-374. 
stały do korporacji międzynarodowej, gdziekolwiek będzie oceniana jej aktywność. Dość wskazać, że statuty osobowe spółek ustalane są na podstawie różnych łączników w różnych państwach, np. miejsca rejestracji, siedziby, centrum działalności czy kontroli. Zastosowanie norm kolizyjnych dla zidentyfikowania statutu osobowego spółek należących do korporacji międzynarodowej nie jest też w stanie nakreślić wszelkich aspektów prawnych działalności tego typu podmiotów. Korporacje międzynarodowe z założenia nie podlegają jednemu statutowi osobowemu w rozumieniu kolizyjnoprawnym.

Nad tym zastanawiała się również doktryna i zaproponowała następujące scenariusze: wobec każdej spółki należącej do holdingu należy stosować odrębne ustawodawstwo, właściwe ze względu na rejestrację (ang. entity approach) lub też podejście uwzględniające ekstraterytorialne zastosowanie norm jakiegoś porządku prawnego do danej korporacji międzynarodowej jako jednego organizmu (ang. extraterritoriality), lub harmonizację w (kilku, wielu, wszystkich) państwach norm dotyczących funkcjonowania korporacji międzynarodowej jako całości (ang. harmonization $)^{35}$. Trudno jednak przyznać, by to zaproponowane przez R. Avi-Yonaha spojrzenie na korporacje międzynarodowe znalazło szerszy odzew przedstawiciel doktryny prawa międzynarodowego $z$ innych państw.

Powyższe rozważania prowadzą do wniosku, że ocena korporacji międzynarodowych wyłącznie z perspektywy prawa prywatnego międzynarodowego i komparatystyki prawniczej nie ujmuje istoty rzeczywistego funkcjonowania korporacji międzynarodowej jako jednego ponadnarodowego organizmu gospodarczego. Co prawda, w niniejszych rozważaniach jednolicie stosowane jest pojęcie "korporacja międzynarodowa", ale wskazać należy, że część doktryny preferuje pojęcie "korporacja transnarodowa”, jako lepiej oddające jednolitość takiego organizmu gospodarczego w połączeniu z okolicznością działalności na terytorium więcej niż jednego państwa (porządku prawnego). F. Rigaux wyróżniał termin les sociétés transnationales z tego względu, że w członie transnationales kryje się pewna "autonomia", niezależność podmiotu od państw, w których organizm gospodarczy działa ${ }^{36}$. Autor ten przypomina także pewną okoliczność, która wpływała na ugruntowywanie się

${ }^{35}$ R.S. Avi-Yonah, National Regulation of Multinational Enterprises: An Essay on Comity, Extraterritoriality, and Harmonization, "Columbia Journal of Transnational Law" 2003, vol. 42, no. 1, s. 5-34, zwł. s. 8.

${ }^{36}$ F. Rigaux, Les sociétés transnationales, Paris 1991, s. 129-139, zwł. s. 129. 
pojęcia "korporacja transnarodowa" (fr. la société transnationale) w miejsce (przykładowo) pojęcia holdingu transnarodowego spółek (fr. groupe transnational de sociétés). W początkowym okresie (lata sześćdziesiąte i siedemdziesiąte ubiegłego wieku) podmioty prowadzące działalność w kilku państwach często powstrzymywały się od zakładania spółek lokalnych, a działalność rozszerzały na inne państwa w ramach agencji i oddziałów, które nie miały odrębnej osobowości prawnej.

Podsumowując, stwierdzić należy, że jedynie normy prawa międzynarodowego w sposób jednolity i kompleksowy mogą oddać istotę funkcjonowania korporacji ponadnarodowych jako jednego organizmu gospodarczego.

Po trzecie, jeśli z pryncypialnych powodów odmówimy korporacjom międzynarodowym podmiotowości prawnomiędzynarodowej, to pozostawimy ich aktywność poza kontrolą prawnomiędzynarodową. Wskazać można na pewną niekonsekwencję państw, które w coraz szerszym zakresie i coraz bardziej szczegółowo regulują w porządkach wewnętrznych działalność spółek, podczas gdy tak wiele dzieje się w przestrzeni ponadnarodowej. Wystarczy zadać sobie retoryczne pytania: Czy Polska może wprowadzić skuteczną poza swymi granicami regulację mającą zastosowanie do korporacji międzynarodowych? A czy jakiekolwiek państwo lub organizacja międzynarodowa może to skutecznie uczynić?

W konsekwencji powyższych stwierdzeń funkcjonowanie korporacji ponadnarodowych skłania prawników do opisywania stanu prawnego poprzez odwoływanie się do zagadnień ekonomicznych, socjologicznych i politycznych, w miejsce poszukiwań normatywnych i prawnej istoty wielu zjawisk i zagadnień. Korporacje międzynarodowe są właśnie dla prawników międzynarodowych takim „zjawiskiem” i „fenomenem", który pojawił się, funkcjonuje i rozwija już kilka dziesięcioleci, a podczas tych dziesięcioleci ani nie zdecydowano się tego rozwoju wspierać, ani też państwa nie są jednomyślne w tym, czy mu przeszkadzać. Tymczasem można z dużą śmiałością sformułować tezę, że społeczność międzynarodowa ma interes w uregulowaniu działalności korporacji międzynarodowych zwłaszcza w zakresie wykraczającym poza granice jurysdykcyjne państw. Prawo międzynarodowe jest tym porządkiem prawnym, który w podejściu do tych podmiotów gwarantowałby spójność. Ostatecznie przyznanie podmiotowości prawnomiędzynarodowej korporacjom międzynarodowym byłoby nade wszystko zatwierdzeniem pewnego stanu faktycznego i rzeczywistej obecności tych podmiotów w stosunkach międzynarodowych. 


\section{Narzędzie nadmiernego faworyzowania korporacji międzynarodowych $i$ inne argumenty przeciw podmiotowości korporacji międzynarodowych w systemie prawa inwestycyjnego}

Zagadnienie podmiotowości korporacji międzynarodowych postrzegane jest jako kontrowersyjne. Korporacje międzynarodowe są już obecnie potężnymi i niekontrolowanymi aktorami międzynarodowych stosunków gospodarczych, zaś podmiotowość prawnomiędzynarodowa jawi się jako przypieczętowanie tego faktu, a nawet jako ryzyko pogłębienia tendencji. Kwestia uregulowania praw i obowiązków korporacji międzynarodowej staje się w coraz większym stopniu koniecznością, przy czym konsekwencje i skuteczność takich regulacji są trudne do przewidzenia.

H. Eidenmüller wymienia kilka czynników, które sprzyjają faktycznemu wzmocnieniu roli korporacji międzynarodowych. Podmioty te mają dzięki skali prowadzonej działalności ułatwiony dostęp do źródeł inwestycji i majątku trwałego, mogą stosować w stosunkach handlowych ze swoimi partnerami wypracowane wzorce umowne, narzucać warunki co do jakości produktu czy też narzucać warunki pracownicze, a także poszukiwać alternatyw wobec dotychczasowych warunków prowadzenia działalności gospodarczej (ang. nonagreement alternatives) ${ }^{37}$. Korporacja międzynarodowa jest tego typu podmiotem, któremu okoliczność funkcjonowania na styku wielu ustawodawstw, paradoksalnie, służy czy też może służyć (w technokratycznej nowomowie - jest „wyzwaniem”), albowiem podmioty te mają dostęp do fachowej obsługi prawnej specjalizującej się w obrocie transgranicznym. Korporacja międzynarodowa może w takich warunkach sprawnie dywersyfikować ryzyko prawne.

Biorąc powyższe pod uwagę, należy się zastanowić, czy ustanowienie podmiotowości prawnomiędzynarodowej korporacji międzynarodowej nie będzie negatywnie wpływać na wolność gospodarczą i równość wszystkich podmiotów w międzynarodowym obrocie gospodarczym. Jeśli nawet przyznanie podmiotowości prawnomiędzynarodowej będzie satysfakcjonować obrońców praw człowieka (metoda "kija”), to czy nie skutkuje to dalszym wzmocnieniem tych podmiotów jako aktorów międzynarodowych stosunków gospodarczych (metoda "marchewki")?

${ }^{37}$ H. Eidenmüller, The Transnational Law Market, Regulatory Competition, and Transnational Corporations, „Indiana Journal of Global Legal Studies” 2011, vol. 18, no. 2, s. 707-749, zwł. s. 727-729. 
Kilka czynników warunkować będzie to, że korporacje międzynarodowe mogą znaleźć się w wyjątkowo korzystnej sytuacji prawnej.

Po pierwsze, jeśli ustanowieniu podmiotowości prawnomiędzynarodowej nie będzie towarzyszyć przemodelowanie systemu ochrony inwestycji zagranicznych, to podmioty te będą mogły (co już jest faktem) korzystać ze znacznie bardziej rozbudowanego instrumentarium dochodzenia roszczeń niż to, które jest dostępne dla podmiotów wyłącznie prawa wewnętrznego. Podmiotowość międzynarodowa dla korporacji międzynarodowych oznaczać będzie bowiem możliwość uciekania się do jednego z następujących mechanizmów: do tradycyjnego mechanizmu ochrony dyplomatycznej państwa ojczystego (pochodzenia) spółki, którym to państwem ojczystym co do zasady, zgodnie z przyjętym orzeczeniem MTS z 1970 r. w sprawie Barcelona Traction, byłoby państwo rejestracji, a także do ochrony przewidzianej w umowach dotyczących ochrony inwestycji lub też do środków przewidzianych w określonym porządku wewnętrznym. Korporacja międzynarodowa jako odrębny podmiot prawa międzynarodowego może w przyszłości również testować samodzielne dochodzenie roszczeń od państw (np. w ramach jurysdykcji nieobligatoryjnej MTS, na podstawie art. 38 Statutu MTS).

Po drugie, prawo międzynarodowe może być źródłem dalej idących dla korporacji międzynarodowej uprawnień, niż to wynika z prawa wewnętrznego. Porządek prawny międzynarodowy może też sanować niektóre aspekty działalności gospodarczej, które dany porządek wewnętrzny uznaje za niezgodne $z$ prawem, niebezpieczne lub sprzeczne z porządkiem publicznym danego państwa.

Po trzecie, obecność korporacji międzynarodowych może być wymierzona w stabilność stosunków międzynarodowych. Wzmocnienie roli korporacji w stosunkach międzynarodowych może spowodować dalsze pogłębienie problemów zależności ekonomicznej państw rozwijających się od konkretnych grup kapitałowych. Jeśli w ramach tzw. "marchewki" korporacjom międzynarodowym zagwarantuje się w powszechnie obowiązujących normach standardy wynikające z BIT-ów, to problemy państw w zakresie realizacji polityk gospodarczych i społecznych zaostrzą się (ta problematyka szerzej opisana została w paragrafie siódmym niniejszego artykułu).

Po czwarte, przyjmując, że specyfiką systemu prawa międzynarodowego jest to, iż podmioty tego porządku prawnego same stanowią dla siebie normy, to włączenie do systemu grupy podmiotów o zdecydowanie wykrystalizowanych oczekiwaniach (głównie maksymalizacji zysku 
i optymalizacji funkcjonowania) może skutkować tym, że w przyszłości zdejmie się z państw cały ciężar lub część ciężaru "odpowiedzialności” za kierunek rozwoju prawa międzynarodowego, a taki mechanizm może osłabiać i demobilizować państwa. Podmiotowość prawnomiędzynarodowa umocni oczekiwania korporacji międzynarodowych wobec środowiska międzynarodowego w zakresie partycypacji tych podmiotów w procesach decyzyjnych i negocjacji tekstów traktatów (także w zakresie ich decydującego wpływu na treść norm traktatowych).

Po piąte, "upodmiotowienie" korporacji międzynarodowych spowoduje, że dalsze uprzywilejowane traktowanie "nierodzimych" podmiotów (tzw. zagranicznych inwestorów) utraci swoje aksjologiczne podstawy. Międzynarodowe prawo inwestycyjne ma swoje źródło w tradycyjnej (wywodzącej się jeszcze z czasów średniowiecza) ochronie słusznych praw „obcych" (ang. rights of aliens), osób podlegających innej jurysdykcji personalnej, na terytorium państwa goszczącego. Co do zasady cudzoziemcy, nawet jeśli są podmiotami niedyskryminowanymi w obrocie handlowym, są podmiotami o faktycznie słabszej pozycji w państwie goszczącym nie tylko ze względu na okoliczność naturalnej (nawet nieuchwytnej i niezwerbalizowanej) chęci wspierania podmiotów "rodzimych" i własnych obywateli, ale także ze względu na okoliczności natury prawnej: cudzoziemcy nie mają praw wyborczych, a w konsekwencji nie mają wpływu na wybór władz kraju i kierunek prowadzonej przez dane państwo polityki gospodarczej. Jeśli korporacja międzynarodowa zyska podmiotowość prawnomiędzynarodową uniezależniającą ją od jakiegokolwiek państwa (a więc niepodlegającą żadnej jurysdykcji personalnej), to czy wówczas da się uzasadnić postrzeganie uczestników obrotu gospodarczego w kategoriach podziału na podmioty "rodzime” i „obce"?

\section{Pogodzenie interesów państw i korporacji międzynarodowych, czyli o przyszłości podmiotów międzynarodowego prawa inwestycyjnego}

Problemem, który w dużej mierze paraliżuje wszelkie dyskusje na temat podmiotowości prawnomiędzynarodowej korporacji międzynarodowych jest zakres uprawnień i pozycji prawnej korporacji międzynarodowej po przesądzeniu kwestii ich podmiotowości prawnomiędzynarodowej. Już we wcześniejszych rozważaniach tego artykułu nawiązano 
do pytania, czy korporacje międzynarodowe powinny być aktorami międzynarodowymi obok państw i cieszyć się tym samym zakresem uprawnień i obowiązków, jakimi cieszą się państwa, czy też powinny mieć odrębny od państw status w ramach kategorii „podmiotów prawa międzynarodowego". Przyjęcie, bądź przesądzenie, określonego rozwiązania w sferze prawa międzynarodowego będzie wpływać na zmiany strukturalne stosunków międzynarodowych, a więc na to, czy korporacje międzynarodowe będą aktorami stosunków obok państw, czy nastąi asymilacja ich pozycji faktycznej i prawnej, czy przyznanie podmiotowości prawnomiędzynarodowej tym podmiotom nie spowoduje konieczności rozważenia podmiotowości NGO-sów, czy wreszcie korporacje będą mogły aktywnie uczestniczyć w kształtowaniu norm traktatowych ich dotyczących i w ogóle norm prawa międzynarodowego. Kwestia zakresu i wpływu podmiotowości prawnomiędzynarodowej korporacji międzynarodowych to jednak tylko część problemu, i to o wtórnym charakterze wobec celów takich tendencji.

W tych okolicznościach kluczowym zagadnieniem jest określenie celu, dla którego społeczność międzynarodowa byłaby skłonna rozwijać w obszarze międzynarodowego prawa inwestycyjnego podmiotowość prawnomiędzynarodową korporacji międzynarodowej. Zaznaczyć należy z góry, że interesy państw i korporacji międzynarodowych moga być dalece rozbieżne. Państwa mogłyby być zainteresowane kontrolą przepływów kapitałowych i przeprowadzanych inwestycji, przy czym te procesy może na własne potrzeby kontrolować indywidualnie każde państwo bez konieczności uciekania się do regulacji międzynarodowych. Korporacje międzynarodowe mają zaś interes w pozyskaniu istotnego atrybutu, jakim jest możliwość pozywania państw przed sądy międzynarodowe. Jednakże, jeśli tylko podmiotowość prawnomiędzynarodowa korporacji międzynarodowych miałaby służyć do stworzenia nowego mechanizmu ochrony inwestycji dokonanych przez te podmioty, w większym stopniu uniezależnionego od indywidualnych "koncesji” państw w zakresie polityki popierania inwestycji, to oczywiste jest, że koncepcja takiej podmiotowości korporacji międzynarodowych może znaleźć bardzo wielu oponentów wskazujących na niecelowość takich rozwiązań.

Obecny system międzynarodowego prawa inwestycyjnego (dwustronnych lub wielostronnych umów typu BIT, umów handlowych i współpracy gospodarczej czy norm prawa międzynarodowego wynikających z członkostwa w organizacjach międzynarodowych, np. WTO, OECD czy NAFTA) już w dostatecznie daleko idący sposób faworyzuje 
inwestorów kosztem państw. Wszelkie klauzule w umowach inwestycyjnych dotyczące traktowania niedyskryminacyjnego, wprowadzające wobec inwestorów zagranicznych bardzo korzystne rozwiązania dotyczace ich traktowania (np. klauzule najwyższego uprzywilejowania KNU czy traktowania narodowego), połączone często z klauzulą niepogarszania standardów, w rzeczywistości paraliżują państwa przed wdrażaniem śmiałych polityk interwencyjnych w gospodarce, tj. polityk aktywizacji zawodowej określonych grup społecznych czy regionów, polityk w zakresie ochrony praw pracowniczych (np. kobiet, osób starszych), w zakresie ochrony praw dziecka (np. wprowadzenia minimalnego wieku do podjęcia pracy czy ochrony przed wyzyskiem), przepisów dotyczących bezpieczeństwa i higieny pracy, w zakresie ubezpieczeń od nieszczęśliwych wypadków, ubezpieczeń społecznych, przepisów środowiskowych, polityki zagospodarowania przestrzennego, wprowadzania środków podyktowanych potrzebami i zagrożeniami bezpieczeństwa i porządku publicznego. Dość przypomnieć w tym miejscu kontrowersyjną skargę z 2012 r. do trybunału arbitrażowego złożoną przez francuską firmę energetyczną Veolia przeciw rządowi Egiptu, w której francuski inwestor domagał się odszkodowania od rządu Egiptu na podstawie postanowień umowy BIT, a źródłem dochodzonej szkody i naruszenia postanowień BIT (normy prawa międzynarodowego) było podniesienie w Egipcie wysokości płacy minimalnej ${ }^{38}$.

Uprzywilejowanie korporacji międzynarodowych (inwestorów) wobec państw ma charakter systemowy w ramach obecnych mechanizmów rozstrzygania sporów na podstawie BIT. Państwa nie mają równorzędnego $z$ inwestorami uprawnienia do wnoszenia skarg przed trybunały międzynarodowe. Nawet jeśli inwestor zagraniczny narusza istotne interesy lokalnej społeczności, to ta jest zupełnie pozbawiona możliwości uciekania się do niezależnego ponadnarodowego organu rozstrzygającego (trybunału arbitrażowego) w celu ustalenia, czy tego typu działanie miało rzeczywiście miejsce. Państwa nie mogą składać również powództw wzajemnych wobec skarg wnoszonych przez inwestorów do trybunałów arbitrażowych.

Istotną kwestią jest także wzmocnienie korporacji międzynarodowych $\mathrm{w}$ porównaniu $\mathrm{z}$ innymi uczestnikami międzynarodowego obrotu gospodarczego nieposiadającymi podmiotowości prawnomiędzynarodowej. Umowy o ochronie inwestycji w wyjątkowy sposób

${ }^{38}$ Veolia Propreté v. Arab Republic of Egypt, ICSID Case No. ARB/12/15. 
uprzywilejowały inwestorów $\mathrm{w}$ porównaniu z pozostałymi podmiotami $\mathrm{w}$ międzynarodowym obrocie prawnym, albowiem dały inwestorom swobodny wybór możliwości dochodzenia roszczeń bądź na drodze krajowych środków dochodzenia roszczeń, bądź w oparciu o BIT-y na drodze międzynarodowego arbitrażu inwestycyjnego, z pominięciem krajowych środków dochodzenia roszczeń. Widocznym mankamentem systemu ochrony inwestycji jest brak mechanizmu równoważącego uprzywilejowaną pozycję inwestorów (korporacji międzynarodowych), gdy ci naruszają reguły konkurencji, nadużywają w handlu pozycji dominującej, czy wręcz funkcjonują w ramach struktury międzynarodowych monopoli. Państwa nie mogą jak dotąd pozywać korporacji międzynarodowych w celu dochodzenia w ramach ochrony dyplomatycznej interesów „rodzimych” podmiotów gospodarczych, a obecne tendencje w rozwijaniu podmiotowości korporacji międzynarodowych takich możliwości nie przewidują. Wzmocnienie państw w powyższym zakresie miałoby silne aksjologiczne umocowanie w zasadach równości i niedyskryminacji w przestrzeni międzynarodowej.

Pomimo powyższych wątpliwości można wskazać na takie wartości, co do których społeczność międzynarodowa jako całość mogłaby się jednak porozumieć we wspólnym interesie. Dla zmniejszenia presji silnych ponadnarodowych podmiotów gospodarczych (korporacji międzynarodowych) na rządy państw (zwłaszcza państw rozwijających się) prawo międzynarodowe mogłoby być płaszczyzną regulującą kwestie ochrony i gwarancji uzasadnionych oczekiwań tych podmiotów, w tym ustanawiać adekwatne standardy dostępu do wymiaru sprawiedliwości i administracji poszczególnych państw, zapewniać przejrzystość funkcjonowania tych podmiotów, ustanawiać racjonalne i proporcjonalne działania kontrolne wobec tych podmiotów, a także wprowadzać gwarancje stabilności, przewidywalności i spójności działań rządów wobec korporacji międzynarodowych.

K. Nowrot ocenia, że pozostawienie poza systemem prawnomiędzynarodowym wpływowych aktorów tego systemu nie wydaje się w interesie całej społeczności międzynarodowej, która powinna zastanowić się nad zrównoważonym systemem kontroli funkcjonowania korporacji międzynarodowych na styku z interesami państw (polityk publicznych) i ich obywateli ${ }^{39}$. W doktrynie utrwaliło się jednak dość

${ }^{39}$ K. Nowrot, New Approaches to the International Legal Personality of Multinational Corporations Towards a Rebuttable Presumption of Normative Responsibilities, "Journal of Global Legal Studies" 1993, no. 9, s. 1-26, zwł. s. 8. 
zachowawcze podejście co do możliwości poszerzania obszarów prawa międzynarodowego stanowiących o prawach i obowiązkach korporacji międzynarodowych. Przyjmując tę konserwatywną optykę, C. Vázquez jest z kolei przeciwny wprowadzeniu "nowego ładu” i poszerzania funkcji podmiotowości międzynarodowej korporacji międzynarodowej. Koncentruje się on na obawach państw, że wraz z rozwojem niezależnych od woli państw i niepodlegających im instytucji oraz mechanizmów określających sposób funkcjonowania korporacji międzynarodowych państwa utracą kontrolę nad ich funkcjonowaniem i istotne atrybuty władztwa jurysdykcyjnego ${ }^{40}$. $Z$ tych względów postuluje też, by to jedynie państwa rozwijające się, jako zainteresowane wprowadzeniem równowagi i niedyskryminacji w stosunkach na styku państw i korporacji międzynarodowych, zawarły stosowną umowę międzynarodową regulującą zasady funkcjonowania korporacji międzynarodowych ${ }^{41}$.

Poza kwestią identyfikacji wspólnych dla społeczności międzynarodowej interesów pojawia się wiele pytań dotyczących mechanizmu przestrzegania norm adresowanych do korporacji międzynarodowych. Kto mógłby stanąć na straży takich norm (państwa, organizacje międzynarodowe, wszystkie podmioty prawa międzynarodowego)? Co sprawiałoby, że będą one skuteczne i przestrzegane? Czy należałoby stworzyć nowy model przestrzegania norm adresowanych wyłącznie do korporacji międzynarodowych? Czy byłby to model na wzór systemu ochrony praw człowieka?

Prawo międzynarodowe, poza nielicznymi wyjątkami, zawiera nie normy, które adresuje się do korporacji międzynarodowych, lecz kierowane do państw, ażeby te ostatnie wprowadziły jednolite regulacje dotyczące podmiotów funkcjonujących w międzynarodowym obrocie gospodarczym. Eksperci prawa międzynarodowego oraz społeczność międzynarodowa mogliby alternatywnie rozważyć, czy cele związane z funkcjonowaniem korporacji międzynarodowych dałoby się osiągnąć w ramach harmonizacji rozwiązań przyjmowanych w porządkach wewnętrznych państw.

Powyższa metodologia pozwalałaby uniknąć licznych wątpliwości odnoszących się do charakteru norm dotyczących funkcjonowania korporacji międzynarodowych, tj. tego, czy normy prawa

${ }^{40}$ C.M. Vázquez, Direct vs. Indirect Obligations of Corporations Under International Law, „Columbia Journal of Transnational Law” 2004, no. 43, s. 927-959.

${ }^{41}$ Ibidem, s. 956. 
międzynarodowego miałyby bezpośrednie zastosowanie ${ }^{42}$. To, czy prawa i obowiązki są adresowane do państw czy też do podmiotów prywatnych (korporacji międzynarodowych), ma istotne praktyczne znaczenie. Ważne jest, czy mechanizm kontroli można zastosować wobec osób odpowiedzialnych za spółkę (organów spółek, osób zarządzających i akcjonariuszy). Jeśli prawo międzynarodowe wnikałoby w kwestie funkcjonowania spółek, to musiałoby przyjąć także rozwiązania w zakresie odpowiedzialności osób zarządzających i kontrolujących spółkę. Ażeby możliwe było traktowanie w sposób poważny podmiotowości prawnomiędzynarodowej korporacji międzynarodowych, należy zmienić dwa założenia prawa międzynarodowego: że jedynie państwa są adresatami norm prawa międzynarodowego oraz że jedynie państwa ponoszą odpowiedzialność prawnomiędzynarodową (a w rozważanym przypadku normy prawa międzynarodowego stanowiłyby o odpowiedzialności osoby prawnej i osób fizycznych zarządzających spółką).

Podmiotowość korporacji międzynarodowych stawia także wiele praktycznych pytań i problemów natury systemowej, w tym to zasadnicze: czy państwa w ogóle mogą stanowić o kwestiach funkcjonowania korporacji międzynarodowych, jeśli korporacje międzynarodowe miałyby być docelowo podmiotami w stosunkach międzynarodowych o odrębnej podmiotowości od państw (w prawie międzynarodowym tradycyjnie podmioty tego prawa same stanowią o normach wobec nich adresowanych). Ale z drugiej strony, poza państwami - kto mógłby? Jeśli zaś państwa zgodzą się uregulować zasady prawa międzynarodowego dotyczące funkcjonowania korporacji, to do kogo należeć będzie inicjatywa w zakresie takich regulacji lub ich zmiany? Czy wszystkie państwa będą musiały akceptować takie normy? A co się stanie, jeśli nie wszystkie państwa będą akceptować normy dotyczące funkcjonowania korporacji międzynarodowych i nie przystąpią do takiej konwencji?

Można sobie wyobrazić umowę wielostronna, której celem byłoby uregulowanie funkcjonowania korporacji międzynarodowych i stanowiącą swoistą "konstytucję" dla korporacji międzynarodowych jako podmiotów prawa międzynarodowego, regulującą również w jednolity sposób stosunki ze wszystkimi państwami-stronami w zakresie ochrony inwestycji. Jednakże państwa nie decydują się na uregulowanie

\footnotetext{
${ }^{42}$ Ibidem, s. 927-959.
} 
tej kwestii, w dużej mierze pozostawiając sobie w ten sposób większac swobodę na przyszłość w zakresie możliwości przyciągania do siebie inwestycji zagranicznych.

Na zakończenie nie sposób nie podzielić się także takim spostrzeżeniem, że cała dyskusja o podmiotowości prawnomiędzynarodowej korporacji międzynarodowych jest próbą pogodzenia założeń nurtu ochrony praw człowieka z realiami obrotu gospodarczego i założeń systemu ochrony inwestycji zagranicznych, w którym funkcjonują korporacje międzynarodowe jako "mastodonty", a inwestycje są "towarem” i celem polityki gospodarczej państw (państwa i społeczności lokalne stają się klientami "towarów" oferowanych przez korporacje międzynarodowe). Tu istnieje pewna subtelna różnica między ochroną i wyznaczeniem zakresu praw i obowiązków dla jednostki takiej jak osoba fizyczna oraz korporacji międzynarodowej. W ramach nurtu ochrony praw człowieka starano się upodmiotowić osobę fizyczną na arenie międzynarodowej w celu efektywnej ochrony jej interesów, a w przypadku korporacji ponadnarodowych, ażeby przed nimi się bronić. Międzynarodowe prawo ochrony inwestycji jest obszarem faktycznego faworyzowania interesów inwestorów kosztem państw, można więc spodziewać się oporu wobec koncepcji dalszego rozwijania podmiotowości międzynarodowej korporacji międzynarodowych w tym obszarze prawa.

\section{Podsumowanie}

Na obecnym etapie rozwoju prawa międzynarodowego należy bardzo ostrożnie formułować wnioski przesądzające o ukształtowaniu się podmiotowości prawnomiędzynarodowej korporacji międzynarodowych w obszarze międzynarodowego prawa inwestycyjnego.

W artykule opisano kilka przesłanek pozwalających na stwierdzenie, że korporacje międzynarodowe mają już część atrybutów właściwych podmiotom prawa międzynarodowego. Wiele istotnych praw i obowiązków korporacji międzynarodowej już wynika z norm prawa międzynarodowego traktatowego, na które wyraziły zgodę państwa i których państwa są stronami. Są to głównie normy dwustronnych traktatów, które ze względu na ich liczbę ( w skali globalnej jest ponad 3000 umów BIT) moga, w opinii części doktryny, świadczyć o kształtowaniu się norm prawa zwyczajowego. Korporacje zawierają z państwami również kontrakty dotyczące procesów inwestycyjnych i warunków koncesji, których 
postanowienia poddają ocenie prawa międzynarodowego. Zgodnie ze stanowiskiem wyrażonym w orzeczeniu Texaco-Calasiatic z 1977 r. korporacje międzynarodowe zyskują podmiotowość prawnomiędzynarodową w wyniku zawarcia umowy podlegającej prawu międzynarodowemu. Korporacje międzynarodowe mogą też pozywać przed trybunały arbitrażowe państwa (czyli inne podmioty prawa międzynarodowego) za naruszenie norm prawa międzynarodowego. Korporacje międzynarodowe swoim charakterem i organizacją upodobniają się do państw.

Korporacje międzynarodowe, jeśli je porównać z państwami, wielu atrybutów podmiotowości prawnomiędzynarodowej nie mają. Dotyczy to m.in. suwerenności, terytorium, prawa legacji, władztwa jurysdykcyjnego, stanowienia o wojnie i pokoju czy polityki zagranicznej. Są to podmioty niesamodzielne, a ich działalność podlega w dalszym ciągu (mimo pojawienia się przesłanek podmiotowości międzynarodowej) ocenie porządków prawnych wewnętrznych państw. W przypadku korporacji międzynarodowych można mówić co najwyżej o podmiotowości niepełnej, funkcyjnej, względnej i niesamodzielnej. Nie sposób podmiotowości korporacji międzynarodowej domniemywać, wszystkie przesłanki warunkujące jej posiadanie przez daną korporację międzynarodową należałoby badać i poddawać całościowej ocenie. Przypisanie podmiotowości prawnomiędzynarodowej dla celów odpowiedzialności z tytułu naruszenia norm ius cogens nie będzie przesądzać o podmiotowości w obszarze stosowania międzynarodowego prawa inwestycyjnego.

Jeśli kwestia podmiotowości prawnomiędzynarodowej korporacji zostanie przesądzona, przyszłość dotychczas ukształtowanych norm prawa międzynarodowego dotyczących ochrony inwestycji (w tym ochrony dyplomatycznej państw, BIT-ów, wielostronnych umów międzynarodowych przewidujących ochronę inwestycji) nie jest jasna. W artykule zostały przedstawione główne mankamenty systemu międzynarodowego prawa inwestycyjnego w obecnym kształcie. W systemie tym prawa i obowiązki państw i korporacji międzynarodowych nie są zrównoważone, bowiem w tym obszarze prawa międzynarodowego faworyzuje się inwestorów (a więc także korporacje międzynarodowe). Państwa i społeczności lokalne nie mają możliwości dochodzenia od inwestora szkód związanych z inwestycją czy naruszeniami istotnych interesów społeczności lokalnej. Państwo nie może również wnosić powództw wzajemnych wobec skarg wnoszonych do trybunałów arbitrażowych. Korporacje międzynarodowe dzięki traktatom dotyczącym ochrony 
inwestycji korzystają wedle uznania ze środków dostępnych w prawie państwa inwestycji lub przewidzianych w BIT-ach (umowach międzynarodowych).

Nie wykrystalizowały się też wspólne dla całej społeczności międzynarodowej cele, dla których rozwijano by koncepcję podmiotowości prawnomiędzynarodowej korporacji międzynarodowej. Obecny system uprzywilejowanej pozycji korporacji międzynarodowych wobec państw i innych podmiotów gospodarczych na rynkach lokalnych i międzynawowych jest grą o sumie "niezerowej” dla państw, które za cenę daleko idących ustępstw wobec tych podmiotów w ramach prowadzonej indywidualnie polityki traktatowej kształtują politykę przyciągania na własne terytorium inwestycji zagranicznych. Obecnie ten system przechodzi swoiste "przesilenie”, albowiem coraz głośniejsze są zarzuty, że postanowienia umów o ochronie inwestycji bardzo skutecznie ograniczają wdrażanie polityk interwencyjnych w obszarze polityki społecznej, prawa pracy i ochrony praw osób słabszych na rynku pracy, zagospodarowania przestrzennego czy prawa ochrony środowiska. Uwidacznia się również wspólna dla całej społeczności międzynarodowej potrzeba kontroli działalności korporacji międzynarodowych oraz dokonania oceny ich działalności z punktu widzenia reguł konkurencji i nadużywania pozycji dominującej na rynkach ponadnarodowych.

$\mathrm{Z}$ jednej strony można zidentyfikować wiele wartości, które prawo międzynarodowe mogłoby zabezpieczać korporacjom międzynarodowym w interesie całej społeczności międzynarodowej, w tym stanowić o gwarancjach dla uzasadnionych oczekiwań tych podmiotów, standardach dostępu do wymiaru sprawiedliwości i administracji państw inwestycji, zapewniać przejrzystość funkcjonowania tych podmiotów, ustanawiać racjonalne i proporcjonalne działania kontrolne wobec tych podmiotów, a także wprowadzać gwarancje stabilności, przewidywalności i spójności działań rządów wobec tych podmiotów. Z drugiej strony w obszarze międzynarodowego prawa inwestycyjnego brak jest jednak tak silnych bodźców aksjologicznych do rozwijania koncepcji podmiotowości korporacji międzynarodowych, jak ma to miejsce w przypadku odpowiedzialności prawnomiędzynarodowej za naruszenie norm ius cogens.

Z powyżej wskazanych powodów należy oczekiwać, że kwestia przesądzenia podmiotowości prawnomiędzynarodowej korporacji międzynarodowych będzie związana $\mathrm{z}$ daleko idącymi zmianami w międzynarodowym prawie inwestycyjnym. 


\section{INTERNATIONAL LEGAL PERSONALITY OF TRANSNATIONAL CORPORATIONS AS A CHALLENGE FOR THE SYSTEM OF THE PROTECTION OF FOREIGN INVESTMENTS}

\section{S u m mary}

This paper analyzes two issues: the current state of international investment law as to the question of the subjectivity of transnational corporations and whether this question contributes to changes in the system of protection of foreign investments.

Transnational corporations have already some relevant attributes of the subjects of international law, although all we can say is that their international legal personality is incomplete, functional, relative and not independent. International legal personality of transnational corporations cannot be presumed and if it for the purpose of assigning liability for infringements of the rules of jus cogens, this will not prejudge the subjectivity in the field of the use of international investment law.

If international legal subjectivity of a transnational corporation has been decided upon, the future of the already existing norms of international law regarding the protection of investments (including diplomatic protection, BIT provisions and multilateral international agreements) is not clear. In this system, the rights and obligations of states and transnational corporations are not balanced as this area of international law favours investors (and thus also transnational corporations). States and local communities are neither entitled to claim damages from the investor when such damages are caused by an investment or if they arise from violations of the vital interests of the local community, nor may they bring counterclaims against the complaint to arbitration tribunals.

Common goals for the whole international community, for which the concept of international legal personality of transnational corporations could be developed, have not as yet been precisely articulated. Unlike it is the case of liability for the international law of jus cogens, there are no strong axiological reasons to develop this concept in international investment law.

Keywords: transnational corporation - (international legal) subjectivity - foreign investments 